\title{
PENDIDIKAN POLEKSOSBUD DAN IDEOLOGI DALAM MEMBANGUN KARAKTER BANGSA
}

\author{
Bagyo Handoko Sutiksna*
}

\begin{abstract}
Facing the era of global markets, the world of education is expected to have a curriculum and syllabus that leads to the formation of a specific competence that is accredited and certified nationally and even internationally so as to link and mach with the real needs of business and labor market and not leave the culture of the nation's culture. Education is to contribute in developing human resources (HR) quality, with indicators of qualified experts, skilled, creative, innovative, and have the attitude (attitude and behavior) is positive. Nation's character development education model (building future leaders) is through the development of the values possessed by Indonesian people become content in the curriculum of global markets.
\end{abstract}

Keywords: global markets, nation's culture, link and mach.

\section{PENDAHULUAN}

Pendidikan nasional dalam perjalanannya sering menimbulkan berbagai masalah dan sering menjadi perbincangan dan kritik di masyarakat. Pendidikan di Indonesia kurang dapat menghasilkan pribadipribadi yang unggul dalam ilmu pengetahuan, akhlak dan kemanusiaan. Saat ini sendi-sendi kehidupan bangsa tengah digoyang berbagai macam aksi kekerasan, kerusuhan, anarki, korupsi, vandalisme dan tindakan-tindakan amoral. Bangsa Indonesia tampaknya sedang terkena kontaminasi "virus" disintegrasi politik, sosial, budaya, dan agama. Masalah politik, sosial, budaya dan agama yang menghiasi Indonesia sejak negeri ini didirikan, rupanya sedang mengalami krisis.

\footnotetext{
* Bagyo Handoko Sutiksna. Dosen Fakultas Ekonomi Universitas Negeri Jakarta
}

Konflik politik, sosial, budaya, dan keagamaan yang terjadi dalam beberapa tahun belakangan ini menunjukkan indikasi adanya krisis multi dimensi.

Fenomena tersebut membuat kesadaran nurani sebagai tenaga pendidik, tersentuh dan mempertanyakan kembali makna pendidikan yang hakiki. Banyak kalangan mulai melihat bahwa model pendidikan Indonesia kurang berbasis pada kemanusiaan, sehingga anak-anak didik dan produk pendidikan rentan terhadap konflik kemanusiaan dan disintegrasi sosial budaya. Munculnya berbagai konflik, ketegangan social, politik, dan keagamaan di tengah-tengah masyarakat menunjukkan indikasi adanya kesalahan mendasar dalam filosofi dan Manajemen Pendidikan di Indonesia. 
Kalangan pendidik perlu mengakui secara terus terang bahwa selama bertahun-tahun dunia pendidikan telah terpasung oleh kepentingan-kepentingan tertentu yang absurd, tersisih diantara hingarbingar ambisi untuk mengejar pertumbuhan ekonomi dan daya saing bangsa. Pendidikan tampaknya kurang diarahkan untuk memanusiakan manusia secara utuh lahir dan batin, tetapi lebih diorientasikan pada hal-hal yang bersifat materialistis, ekonomis dan teknokratis, kering dari sentuhan nilai-nilai moral, kemanusian dan budi pekerti. Pendidikan di Indonesia hanya mementingkan pada kecerdasan intelektual, akal dan penalaran, tanpa diimbangi dengan pengembangan kecerdasan hati, perasaan dan emosi secara intensif. Akibatnya, apresiasi output pendidikan terhadap keunggulan nilai humanistik, keluhuran budi dan hati nurani menjadi dangkal. Mereka sebagai output pendidikan banyak yang menjadi sosok pribadi yang telah kehilangan hati nurani dan perasaan, sehingga cenderung bersikap egoistis dan "aji mumpung". Dalam konteks demikian, pendidikan dianggap telah melahirkan manusia-manusia berkarakter oportunitis, penjilat, hipokrit, hedonis, besar kepala, tanpa memiliki kecerdasan hati, emosi dan nurani. Sehingga tidaklah mengherankan jika kasus-kasus yang merugikan Negara; KKN misalnya, justru sering melibatkan orang-orang berdasi yang secara formal berpendidikan tinggi. Ini artinya, secara implisit, model pendidikan selama ini setidaknya telah memiliki andil terhadap maraknya korupsi, kolusi, dan nepotisme sehingga menyebabkan Negara tergolong sebagai salah satu Negara yang tingkat korupsinya tertinggi di dunia.

Berdasarkan fenomena di atas, perlu dicarikan alternatifalternatif sebagai solusi untuk memecahkan persoalan tersebut. Kemajuan suatu bangsa sangat ditentukan oleh kualitas pendidikan. Oleh karena itu, pendidikan sebagai sarana untuk mencerdaskan kehidupan bangsa memiliki peranan yang sangat strategis, Pendidikan sangat berkontribusi dalam mengembangkan sumber daya manusia (SDM) yang bermutu, dengan indikator berkualifikasi ahli, terampil, kreatif dan inovatif, serta memilki attitude (sikap dan perilaku) yang positif. Berdasarkan paparan tersebut di atas, maka penulis mencoba menuangkan pemikiran dan perhatian besar terhadap permasalahan pendidikan di negeri tercinta ini. Untuk alasan tersebut, penulis memberi judul: Pendidikan Poleksosbud dan Ideologi dalam Membangun Karakter Bangsa.

\section{Aspek Poleksosbud dalam Pendidikan}

Berkaitan upaya dalam peningkatan kualitas Sumber Daya Manusia (SDM) dan peranannya dalam meningkatkan kualitas tenaga kerja, pemerintah telah mengeluarkan kebijakan, di antaranya berupa Undang-Undang No. 20 Tahun 2003 tentang Sistem Pendidikan Nasional 
dan Undang-Undang No. 13 Tahun 2003 tentang ketenagakerjaan. Namun demikian, jika diamati dari kondisi riil yang ada, terlihat adanya ketimpangan antara kebijakan yang diharapkan dan hasil yang dicapai dalam upaya pemerintah meningkatkan kualitas SDM, termasuk kualitas tenaga kerja yang tersedia. Kondisi ini jelas berdampak terhadap pencapaian sasaran utama program pembangunan nasional; yang fokus utamanya adalah dalam aspek pembangunan ideologi bangsa.

Sistem pendidikan yang baik, adalah sistem pendidikan yang dapat menghubungkan institusi sosial, ekonomi dan politik di dalam masyarakat. Satu-satunya cara yang bisa digunakan untuk mendapatkan perubahan signifikan dalam fungsi dan hubungan pendidikan adalah dengan memelopori perubahan terhadap keseluruhan hubungan sosial, ekonomi dan politik yang menjadi ciri suatu pemerintahan; hal ini seperti dinyatakan oleh Martin Cannoy dan Henry M. Levin (1996) sebagai berikut: In contrast, I attempt to demonstrate that the educational system corresponds to the social, economic, and political institutions of our society and that the only way we can obtain significant changes in educational functions and relations is to forge changes in the overall social, economic, and political relationships that characterize the polity.

Reformasi pendidikan tidak dapat berjalan sukses apabila reformasi tersebut justru melanggar prinsip sistem sosial, ekonomi dan sistem politik. Dalam masyarakat yang stabil (non-revolutionary) sistem pendidikan akan selalu diterapkan agar dapat berperan sebagai transmisi budaya dan melanggengkan status quo meski terjadi perdebatan akademik dan visi utopis tentang isu tersebut. Agar dapat mencapai analisis yang lebih sistematis, maka penulis akan memperlihatkan aplikasinya pada berbagai kegiatan sektor pendidikan sebagai upaya evaluasi pencapaian aspek Poleksosbud dalam pendidikan. Adapun sektor pendidikan tersebut adalah sebagai berikut:

1. Pemerintahan

Pemerintahan mengacu pada masyarakat yang terorganisir dengan ideologi dan bentuk pemerintahan tertentu. Lahir dari pemerintahan rangkaian tuntutan atau tujuan kemasyarakatan untuk mentransmisikan budaya dan menghasilkan kembali serta mempertahankan tatanan ekonomi, politik dan sosial. Tuntutan ini berupa hukum yang mendefinisikan dan mempengaruhi sekolah. Selain itu, pemerintah mempengaruhi kegiatan pendidikan dengan menciptakan nilai dan pengharapan pada pihak warga Negara dalam kaitannya dengan peran mereka di masyarakat dan kewajiban pendidikan untuk memenuhi peran tersebut.

2. Anggaran dan Tujuan

Tujuan merefleksikan tuntutan terinstitusionalisasi yang bersifat formal dan informal sehingga masyarakat memperhatikan sekolah dan anggaran merepresentasikan 
sumberdaya yang dialokasikan untuk tuntutan tersebut.

3. Sumberdaya Pendidikan

Pada tahap ini, anggaran pendidikan hanya berguna untuk kepentingan pendidikan bila ditransformasikan ke sumberdaya pendidikan. Dampak anggaran terhadap hasil pendidikan akan sebanding dengan jenis sumberdaya yang dimasukkan ke dalam proses persekolahan.

4. Proses Persekolahan

Latar pendidikan biasanya didominasi oleh pendidik, dalam artian bahwa hanya sedikit keputusan yang dibuat siswa. Bahkan, sebagian besar keputusan tadi akan diberlakukan kepada anak, jauh hari sebelum ia masuk ke lingkup pendidikan dan keputusan tersebut mencerminkan nilai pemerintahan bukan orang yang terlibat dalam proses tersebut.

5. Hasil Pendidikan

Sumberdaya pendidikan yang terseleksi diatur sedemikian rupa untuk mendapatkan hasil pendidikan yang sesuai dengan peran yang diharapkan atas orang dewasa dalam masyarakat. Karena daya tarik populer sekolah didasarkan atas kontribusinya pada kemampuan baca tulis dan pengetahuan yang semakin meningkat; hal ini cenderung menganggap sekolah menghasilkan hasil-hasil kognitif semacam ini. Fakta bahwa sebagian besar kehidupan dicurahkan untuk bekerja, berarti sikap dan hubungan nilai, sifat kepribadian serta perkembangan moral harus dibentuk untuk memenuhi tuntutan ini.
6. Hasil Sosial, Politik dan Ekonomi

Produk akhir dari proses persekolahan adalah dampak yang ditimbulkan hasil persekolahan terhadap penciptaan ulang hasil sosial, politik dan ekonomi yang diinginkan masyarakat. Dalam hal ini, persekolahan mempunyai peran penting dalam mempersiapkan orang untuk mengasumsikan tanggungjawab akhir mereka sebagai orang dewasa.

Adanya

pengaruh

kebudayaan terhadap keberhasilan pembangunan ekonomi seperti yang disajikan oleh Ronald Inglehart dalam Modernization and Post Modernization (1997); dikatakan bahwa:

"By culture, we refer to system of common basic value that helps shape the behavior of the people in a given society. In most preindustrial societies, this value system takes form of religion and change very slowly; but with industrialization and accompanying processes of modernization, these world views tend to become more secular, and open to change. For reasons discussed earlier, the cultures of virtually all preindustrial societies are hostile to social mobility and individual economic accumulation.

Berdasarkan konteks tersebut nampak bahwa adanya pengaruh kebudayaan terhadap pembangunan baik politik, ekonomi, sosial dan budaya. Dalam hal ini ketercapaian harapan kondisi riil dengan kebijakan yang ada akan nampak jelas jika model dan strategi proses pendidikan difungsikan sesuai dengan perkembangan zaman. Betapa 
strategisnya proses pendidikan yang berfungsi mengembangkan kemampuan dan menumbuhkan nilai dan sikap yang serasi dengan tuntutan pembangunan dan kehidupan dewasa ini.

\section{Pendidikan \\ Pembangunan Karakter \\ Ideologi}

Dalam literatur tentang politik negara berkembang, dikenal model negara Otoriter Birokratik (OB) yang mempunyai pengaruh luas dalam mengatasi masyarakat. Negara $\mathrm{OB}$ menggunakan ideologi pembangunan sebagai salah satu landasannya, serta strategi korporatisme dalam rangka mengatur kiprah politik yang ada dalam masyarakat terutama masyarakat lapisan bawah.

Ideologi pembangunan yang juga sering disebut developmentalisme sebenarnya adalah salah satu produk dari pencerahan (enlighment). Prinsip dasar dari pencerahan adalah penduniawian (sekularisasi), penalaran (rasionalisasi) dan pemanusiaan (humanisasi). Dengan menggunakan ketiga landasan itulah maka revolusi industri, ilmu pengetahuan dan reformasi politik dilakukan. Dengan landasan sekularisasi maka proses desakralisasi atau definisasi dalam kiprah kehidupan manusia diselenggarakan sehingga dominasi lembaga-lembaga pendidikan dan ajaran-ajaran agama dihancurkan. Manusia konon dibebaskan dari belenggu dogma dengan segala ratifikasinya.

Rasionalisasi telah merubah wacana dan kiprah manusia yang semula hanya berwawasan kepercayaan menjadi penalaran. Dengan rasionalisasi kehidupan maka dapat dilakukan eksplorasi tanpa batas terhadap alam oleh manusia melalui penggunaan ilmu pengetahuan dan pengembangan teknologi. Alam tidak lagi dianggap sebagai sesuatu yang menyatu dalam kehidupan manusia, sebagai salah satu komunitas wujud (decomunity or being) sebagaimana diyakini oleh masyarakat tradisional, tetapi alam dimengerti sebagai obyek di luar manusia yang harus ditaklukkan.

Manusia dalam pandangan tradisional hanyalah merupakan salah satu dari warga komunitas wujud, kendati yang termulia dan kini mengklaim sebagai pusat segalanya. Manusia bahkan menganggap apa yang di luar dirinya atau di luar pemahaman rasionalnya sebagai sekedar mitos-mitos. Manusia pencerahan dengan demikian menuntut sebuah kesempurnaan bagi dirinya tanpa ketergantungan dengan yang ada di luarnya, maka tidak heran lagi bahwa pencerahan telah melahirkan revolusi dalam pemahaman posisi manusia berhadapan dengan alam dan sesamanya.

Salah satu ide yang berkembang adalah ide kemajuan (the idea of progress) yang pada gilirannya sangat dominan dalam perkembangan peradaban barat. Ide kemajuan inilah yang menjadikan modernitas dan modernisasi. Modernitas dianggap sebagai pandangan dunia yang berbeda dengan dunia lama, bercirikan 
rasionalitas, kemajuan dan kebebasan manusia. Sedangkan modernisasi adalah proses perubahan yang harus dilakukan agar bisa mencapai masyarakat modern tersebut.

Dalam perkembangannya ide modernitas ini kemudian menyatu dengan pertumbuhan kapitalisme, sehingga seolah-olah identik dengannya. Munculnya kolonialisme yang merupakan wahana ekspansi kapitalisme dengan serta merta diklaim oleh para pelakunya sebagai proses kemajuan dan kemodernan. Oleh sebab itu, kaum kolonial menyebut missi penaklukan daerahdaerah baru sebagai proyek peradaban.

Manakala kolonialisme mendapat tantangan besar dan kemudian hancur, ide progress tersebut muncul kembali dalam bentuk ideologis pembangunan yang sebenarnya memiliki "bisa" yang sangat kuat kepada kapitalisme. Seperti diketahui paradigma modernisasi yang kemudian menjadi paradigma dominan di negara-negara berkembang mulai dekade lima puluhan hingga tujuh puluhan memiliki kaitan erat dengan pertumbuhan dan ekspansi kapitalisme global. Berdasarkan konteks tersebut, dapatlah dimengerti bahwa developmentalisme adalah sebagai sebuah ideologi yang sangat potensial bagi aspek Poleksosbud dalam pendidikan karakter bangsa.

Pertanyaan yang muncul adalah bagaimana mencari alternatif bagi model pendidikan pembangunan karakter bangsa (building future leaders). Jika semua sepakat bahwa modernitas dan modernisasi adalah dua hal yang tak terelakkan, masihkah dimungkinkan untuk diupayakannya suatu keterlibatan yang tidak mengulangi pengalamanpengalaman buruk dan dampak negatif seperti saat ini? Jika mungkin, kondisi yang bagaimana dan landasan apa yang digunakan?

Untuk menjawab pertanyaanpertanyaan di atas, diperlukan suatu tinjauan yang serius mengenai ide pembangunan yang masih berlaku saat ini. Peninjauan tersebut harus kembali mempertimbangkan pemahaman tentang pencerahan dan modernitas sebagai produknya. Elemen-elemen positif pencerahan, seperti pembebasan manusia dari kungkungan tradisi dan kemampuan untuk melakukan refleksi, seharusnya menempati posisi sentral dalam diskursus tentang modernitas. Kritikkritik atas modernitas yang telah didominasi oleh rasionalitas instrumental dalam bentuk kapitalisme dan sistem politik yang menindas harus tetap dilakukan. Pada saat yang sama, perlu melakukan penemuan dan pengembangan elemen positif dari modernitas sambil mengupayakan penggalian dan pembaharuan pendidikan terhadap khazanah tradisional yang berasal dari ajaran-ajaran agama sebagai penopangnya.

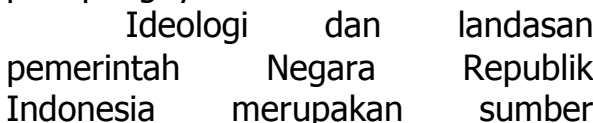
penyelenggaraan pemerintahan termasuk dalam proses pendidikan ideologi di semua jenjang pendidikan. Oleh karena itu seluruh unsur dalam 
proses pembentukan karakter bangsa menuju modernisasi harus disesuaikan dengan landasan Undang-Undang Dasar 1945 dan Pancasila seperti dijabarkan berikut ini.

Salah satu faktor yang mempengaruhi belum mantapnya menyelenggaraan pemerintahan Negara dalam melaksanakan misinya sebagaimana tertulis dalam pembukaan UUD 1945 adalah sukarnya memperoleh konsensus nasional di antara berbagai kekuatan politik untuk berpegang teguh kepada konsensus para pendiri bangsa yang dicapai tanggal 18 Agustus 1945, antara lain meliputi ideologi Negara kebangsaan berdasarkan Pancasila Soedjiarto (2008). Makna pembukaan UUD 1945 sebagai ideologi Negara kebangsaan Indonesia penuh dengan nuansa dan semangat kebangsaan pendiri Republik Indonesia saat berjuang bagi tegaknya Negara Kesatuan Republik Indonesia di bumi Nusantara.

\section{Pendidikan Budi Pekerti di Sekolah}

Budi pekerti artinya watak, perangai, akhlak; demikian entri dalam kamus besar bahasa Indonesia. Pengertian budi pekerti dalam pendidikan yang dimaksud, merupakan kegiatan pendidikan yang menanamkan nilai-nilai ke dalam budi orang. Orang itu siapa? Ia adalah manusia yang perlu dibentuk. Kanakkanak, anak dan remaja (antara 0 tahun sampai 20 tahun). Jika sesudah umur 20 tahun masih harus dididik artinya pendidikan gagal.
Penanaman nilai-nilai dalam pembentukan watak merupakan proses informal, tidak ada pendidikan formal. Jadi seluruh pembentukan moral manusia muda hanya mungkin lewat interaksi informal antara dia dan lingkungan hidup manusia muda itu. Sehingga pendidik utama dalam hal ini adalah orang tua. Dalam menunaikan tugas ini orang tua dibantu oleh masyarakat, karena masyarakat perlu mengatur kebutuhan hidup di dunia ini. Usaha meraih tujuan hidup sebagai makhluk berkebudayaan dan bermasyarakat berlangsung melalui perkembangan keserasian manusia muda menurut segi pandangan moral, intelektual dan fisik.

Kegiatan pendidikan dalam hal ini sekolah adalah pembantu orang tua pada bidang yang tidak dapat ditangani oleh orang tua sendiri, yakni pengajaran. Orang tua berharap kepada sekolah hendaknya anaknya dapat diberi pengajaran hingga siap memasuki dunia sebagai orang dewasa yang berpendidikan sesuai dengan keadaan dan kebutuhan. Sekolah yang sadar akan tanggung jawab terhadap tugasnya harus berfungsi sebagai lembaga pengajaran. Akan tetapi apakah proses pembelajaran hanya memerhatikan ranah kognitif? Apakah masih ada tempat dan waktu untuk menanamkan nilai-nilai untuk pembentukan moral?

Ini adalah suatu masalah, permasalahannya ialah bahwa untuk pendidikan budi pekerti tidak ada kurikulum dalam proses pembelajarannya, sehingga tidak 
memiliki bahan ajar. Buku mengenai budi pekerti yang diterbitkan oleh Depdiknas bukan buku pelajaran, buku tersebut tidak disusun oleh Direktorat Jenderal Pendidikan Dasar dan Menengah akan tetapi oleh Direktorat Jenderal Kebudayaan. Budi pekerti adalah karakter, akhlak dan juga nama untuk cara membentuk karakter, yang merupakan penghayatan cara hidup dan filsafat hidup. Bukan pemahaman, bukan pengertian, tidak ada teologi, sehingga tidak ada budi pekerti sebagai bahan pengajaran.

Selain itu metode yang digunakan pendidik diharapkan dapat mendidik para pelajar menjadi orang berbudi pekerti lewat proses pembelajaran, sehingga dalam kegiatan pendidikan di sekolah tanggung jawab pokok untuk pembentukan moral maupun intelektual dari pelajar tidak terletak pada salah satu prosedur atau kegiatan intrakurikuler atau ekstrakurikuler akan tetapi pada pengajar. Sekolah merupakan tempat kebersamaan hubungan personal otentik pelajar, antara para pelajar sehingga pelajar dapat berkembang. Jadi tidak lewat ekstra kurikuler atau "plusnya" atau asrama, tetapi lewat pengajaran nilai-nilai yang ditanamkan. Pengajar yang mengajar dan membentuk manusia muda menjadi pribadi dewasa merupakan kunci dalam proses pembelajaran Proses pembelajaran seharusnya merupakan "konteks anak, pengalaman anak, refleksi oleh anak, kegiatan anak dan evaluasi". Pengalaman yang paling berharga adalah pengalaman pribadi. Akan tetapi bagi anak sekolah belum mungkin mendapatkan hal tersebut, maka sekolah harus menyediakan mempersiapkan pengalaman tersebut, baik apa yang diajarkan maupun tingkah laku mereka sehingga dapat dijadikan bahan untuk tahap kemudian yaitu refleksi. Namun refleksi itupun harus dibimbing dengan mengajukan pertanyaan yang menimbulkan reaksi para pelajar yang kemudian dirumuskan dalam penilaian mereka atas apa yang diterima dalam pengajaran dari para guru maupun yang dilihat dalam cara para guru bersikap terhadap masalah-masalah yang diajarkan.

Penilaian para pelajar ini merupakan penilaian nilai (value judgment). Dengan demikian pada tahap ketiga kegiatan diangkat pada tingkat nilainilai. Memang cara ini menuntut banyak kepada para guru, karena mereka dengan demikian bukan hanya dituntut untuk menjadi pengajar melainkan juga untuk menjadi pendidik atau lebih tepat pembentuk, sehingga diharapkan para murid mereka akan siap untuk memasuki perguruan tinggi atau dunia kerja.

Model pembelajaran yang dapat bermakna sebagai proses pembudayaan dan pembentukan karakter adalah proses pembelajaran yang hendaknya dapat merangsang, menantang dan menyenangkan sesuai dengan Empat Pilar yang merupakan didasarkan atas consensus Unesco melalui International Commission on 
Education for The Twenty Fist Century berikut ini:

If it is to succeed in its tasks, education must be organized around four fundamental types of learning which, throughout a person's life, will in a way be the pillars of knowledge: learning to know, that is acquiring the instruments of understanding; learning to do, so as to be able to act creatively on one's enviroment; learning to live together, so as to parcipate and co-operate with other people in all human activities; and learning to be, an essensial progression which proceeds from the orevious three. Of cource, these four paths of knowledge all form a whole, because there are many points of contact, intersection and exchange among them (Jacques Delors, 1998).

\section{Rekomendasi Masalah}

Kemajuan suatu bangsa
sangat ditentukan oleh kualitas
pendidikan. Oleh karena itu
pendidikan sebagai sarana untuk
mencerdaskan kehidupan bangsa
memiliki peranan yang sangat
strategis. Pendidikan berkontribusi
dalam mengembangkan sumber daya
manusia yang bermutu dengan
indikator berkualifikasi ahli, trampil,
kreatif, inovatif serta memiliki sikap
dan perilaku yang positif. Untuk itu
penulis merekomendasikan
berdasarkan kajian sebagai berikut:

1) Lembaga pendidikan sebagai salah satu institusi yang sangat berdampak terhadap pencapaian sasaran utama program pembangunan nasional yang fokus utamanya adalah dalam aspek pembangunan ideologi. Sekolah harus dapat memelopori perubahan terhadap keseluruhan hubungan sosial, ekonomi dan politik yang menjadi aspek utama dalam proses pembelajaran di lingkungan sekolah.

2) Menghadapi era pasar global, dunia pendidikan harus memiliki kurikulum dan silabus yang mengarah pada pembentukan kompetensi tertentu yang terakreditasi dan tersertifikasi secara nasional dan bahkan internasional sehingga dapat link and mach dengan kebutuhan riil dunia usaha dan pasar kerja, dengan tidak meninggalkan kultur budaya bangsa kita.

3) Diperlukan adanya upaya dan komitmen bersama untuk melakukan sinkronisasi dan integrasi antara sistem pendidikan nasional dengan arah landasan pendidikan nasional kita yang tidak mengesampingkan ideologi, nilai-nilai, perilaku, moral dan budaya bangsa.

4) Penanaman nilai-nilai dalam mengembangkan disiplin ilmu pendidikan terutama dalam proses pendidikan politik, memajukan kebudayaan nasional dan pendidikan demokrasi dalam menciptakan manusia yang cerdas, kritis dan berpotensi harus tergambar dalam kurikulum pembelajaran di sekolah.

\section{PENUTUP}

Dalam menyoroti kedudukan Pancasila sebagai falsafah dasar bagi 
penyelenggaraan pendidikan nasional, penulis berpendapat diperlukan adanya rancangan dan penyelenggaraan pendidikan nasional yang lebih berpikir "maju" sebagai perwujudan bahwa Pancasila memiliki arti penting dalam membentuk karakter bangsa. Dengan demikian akan dapat berdampak terhadap pencapaian sasaran utama program pembangunan nasional yang fokus utamanya adalah dalam aspek pembangunan ideologi bangsa.

\section{DAFTAR PUSTAKA}

Cannoy, Martin dan Levin Henry M. 1996. The Limits of Educational Reform. New York: David McKay company, Inc.
Joseph Fisker. 2000. The Social Sciences \& The Comparative Studi of Educational Systems.

Jacques Delors. 1998. Learning: The Treasure Within, (Unesco Publishing The Australian National Commision for Unesco).

Ronald Inglehart. 1997. Modernization and Post Modernization: Cultural, Economic and Political change in 43 Societies. Princeton: Princeton University Press.

Soedijarto. Landasan dan Arah Pendidikan Nasional Kita. Jakarta: Kompas. 2008.

Unesco Publishing. 2001. Our Creative Diversity: Report of The World Commission on Culture and Development. 